\title{
Efek Pemberian Dosis ZA pada Lahan Tercemar Logam Berat Timbal terhadap Pertumbuhan dan Akumulasi Pb pada Tanaman Puring (Codiaeum variegatum L.) dan Lidah Mertua (Sansevieria trifasciata L.)
}

\author{
Elina Uswatun Hasanah ${ }^{1 *}$, Anis Rosyidah ${ }^{1}$ dan Mahayu Woro Lestari ${ }^{1}$ \\ ${ }^{1}$ Departemen Agroteknologi, Fakultas Pertanian, Universitas Islam Malang, \\ Jalan MT. Haryono, No. 193, Malang 65144, Jawa Timur, Indonesia \\ Email korespondensi: elinauswah@gmail.com
}

\begin{abstract}
Abstrak
Penelitian ini bertujuan untuk melakukan fitoremediasi dengan menambahkan pupuk untuk meningkatkan biomassa tanaman hiperakumulator. Penelitian ini merupakan percobaan yang dilakukan di Greenhouse dan Laboratorium di Fakultas Pertanian Universitas Islam Malang yang dimulai pada bulan September hingga November 2018. Percobaan ini menggunakan rancangan acak kelompok (RAK) faktorial yang terdiri dari 2 faktor. Faktor pertama pemberian beberapa Dosis ZA terdiri dari tiga level, yaitu kontrol (P0), ZA $100 \mathrm{~kg} \mathrm{~N} \mathrm{ha}^{-1}$ (P1), ZA $200 \mathrm{~kg} \mathrm{~N} \mathrm{ha}^{-1}$ (P2) dan faktor kedua macam tanaman terdiri dari dua level, yaitu tanaman puring (T1), tanaman lidah mertua (T2). Hasil penelitian menunjukkan bahwa perhitungan TF logam berat Pb berkisar antara 0.64 sampai 0.95 menunjukkan nilai $\mathrm{TF}<1$ dan dikategorikan pada strategi fitoremediasi fitostabilisasi. Hasil penelitian ini menunjukkan bahwa tanaman puring (Codiaeum variegatum L.) membutuhkan dosis optimal pupuk ZA $95 \mathrm{~kg} \mathrm{~N}^{-1}$ dengan kadar serapan $\mathrm{Pb}$ 0,43875 ppm dan tanaman lidah mertua (Sansevieria trifasciata L.) membutuhkan dosis pupuk ZA optimum $116,7 \mathrm{~kg} \mathrm{~N} \mathrm{ha}^{-1}$ dengan kadar serapan $\mathrm{Pb} 0,37383$ ppm.
\end{abstract}

Kata kunci: Pupuk ZA, Akumulasi Pb, Codiaeum variegatum L., Sansevieria trifasciata $\mathrm{L}$.

\begin{abstract}
This research aimed to apply a phytoremediation process by adding fertilizer to increase the biomass of hyperaccumulator plants. This research was an experiment conducted in the Greenhouse and Laboratory of Faculty of Agriculture,University of Islam Malang which began in September to November 2018. This experiment used a factorial randomized block design (RBD) consisting of 2 factors. The first factor was the administration of several Doses of ZA consisting of three levels, namely control (P0), ZA $100 \mathrm{~kg} \mathrm{~N} \mathrm{ha}^{-1}$ (P1), ZA $200 \mathrm{~kg} \mathrm{~N}^{-1}$ (P2) and the second factor of plant species consists of two levels, (puring plants (T1), lidah mertua plants (T2)). The results showed that the calculation of TF of $\mathrm{Pb}$ ranged from 0.64 to 0.95 . It is categorized into phytoremediation phyto-stabilizationcategoy. The optimal dosage of ZA for puring plants needed was $95 \mathrm{~kg} \mathrm{~N}^{-1}$ with $\mathrm{Pb}$ Absorption 0,43875 ppm, whole the optimal dosage of ZA for lidah mertua plants was $116,7 \mathrm{~kg} \mathrm{~N}$ ha $^{-1}$ with $\mathrm{Pb}$ absorbtiohn 0,37383 ppm.
\end{abstract}

Keywords: ZA fertilizer, Pb accumulation, Codiaeum variegatum L., Sansevieria trifasciata L. 


\section{Pendahuluan}

Penggunaan logam berat dan senyawa anorganik secara intensif di dalam industri telah banyak digunakan dalam berbagai kegiatan seperti: pertanian, pertambangan, peleburan dan pelapisan logam. Kegiatan pertanian saat ini masih banyak yang menggunakan insektisida yang mengandung timbal $(\mathrm{Pb})$ arsenat. Pemakaian insektisida yang terus menerus dilakukan dalam kegiatan budidaya di lahan pertanian ini, semakin lama $\mathrm{Pb}$ maka akan membahayakan lingkungan dan organisme yang hidup di dalamnya, karena $\mathrm{Pb}$ telah terakumulasi dalam tanah (Mukhlis et al. 2011).

Salah satu teknologi alternatif untuk memulihkan tanah yang tercemar logam berat adalah menggunakan tanaman (fitoremediasi). Cara ini lebih efesien dan ramah lingkungan (Mangkoediharjo, 2005). Tanaman lidah mertua (Sansevieria trifasciata L.) dan puring (Codiaeum variegatum L.) termasuk jenis tanaman hiperakumulator yang berfungsi untuk meremediasi tanah yang tercemar logam berat $\mathrm{Pb}$. Lidah mertua memiliki kemampuan menyerap konsentrasi Pb dalam tanah sebesar 56,63\% (Yusuf et al., 2014). Menurut Sapta dan Hapsari (2012) dalam Kurniawati, dkk (2016) bahwa kemampuan tanaman dalam menyerap logam $\mathrm{Pb}$ dari 2 jenis tanaman yaitu puring $(22,89 \%)$ dan lidah mertua (2,91\%). Upaya lainnya yang dapat dilakukan agar pelaksanaan fitoremediasi berhasil adalah dengan menambahkan pupuk untuk meningkatkan biomassa tanaman hiperakumulator. Penggunaan pupuk anorganik yang mengandung nitrogen (ZA) ditambahkan karena dapat menyediakan nutrisi bagi tanaman sehingga dalam dosis yang tepat akan menghasilkan pertumbuhan biomassa yang tinggi, juga untuk menambah kemasaman tanah untuk meningkatkan kertersediaan logam di dalam tanah (Wati et al., 2019). Ammonium sulfat (ZA) atau $(\mathrm{NH} 4)^{+}$dan sulfat $(\mathrm{SO} 4)^{-2}$ yang selanjutnya ion sulfat dapat berikatan dengan ion $\mathrm{Pb}^{+2}$ dan membentuk PbSO4 yang dapat diserap akar tanaman (Gurnita et al., 2017).

\section{Bahan dan Metode}

Penelitian dilaksanakan di rumah kasa (Fakultas Pertanian Universitas Islam Malang, Jl. MT Haryono, kec Lowokwaru, kota Malang). Ketinggian tempat penelitian adalah 540 meter diatas permukaan laut dan suhu antara $22,7^{\circ} \mathrm{C}-30^{\circ} \mathrm{C}$. Penelitian dimulai pada tanggal 18 September 2018 sampai 22 November 2018.

Penelitian dilakukan dengan Rancangan Acak Kelompok (RAK) yang disusun secara faktorial dan terdiri 2 faktor yaitu dosisi pupuk dan jenis tanaman. Faktor pertama adalah dosis pupuk ZA (P0= kontrol (tanpa ZA), P1= ZA dosis 100kg N/ha-1, 
dan P2= ZAVdosis $200 \mathrm{~kg} \mathrm{~N} / \mathrm{ha}-1)$ dan faktor kedua adalah jenis tanaman (T1= tanaman puring (Condiaeum variagetum L.) dan $\mathrm{T} 2=$ tanaman lidah mertua (Condiaeum variagetum L.)). Masing-masing perlakuan dalam satu ulangan terdiri atas 3 sampel tanaman. Setiap perlakuan diulang sebanyak 3 kali dengan 3 sampel tanaman sehingga diperoleh 54 perlakuan tanaman.

Media tanam yang digunakan adalah campuran tanah dan pasir (4:1) sebanyak 5 kg. Selanjutnya media tersebut ditambahkan bahan organik kotoran ayam $200 \mathrm{~kg} \mathrm{ha}^{-1}$ sesuai perlakuan. Timbal di aplikasikan 1 minggu sebelum tanam, dengan konsentrasi $350 \mathrm{mg} / \mathrm{kg}$ tanah (1,75 gram/polybag). Selanjutnya dilakukan penanaman tanaman digunakan adalah tanaman puring dan lidah mertua berumur 3 bulan dengan jumlah daun 10 helai dan 1-3 helai serta tinggi tanaman berkisar $30 \mathrm{~cm}$ dan $50-90 \mathrm{~cm}$. Penanaman dilakukan setelah tanaman dialimatisasi selama 1 bulan. Penanaman tanaman puring dan lidah mertua dilakukan pada sore hari. Parameter yang diamati dalam penelitian ini meliputi tinggi tanaman, jumlah daun, konsentrasi $\mathrm{Pb}$ pada akar dan tajuk, konsentrasi $\mathrm{Pb}$ pada media dan nilai translocation factor. Analisa konsentrasi $\mathrm{Pb}$ dilakukan dengan metode $\mathrm{AAS}$ dan dilakukan di Laboratorium Pusat dan Halal Center Universitas Islam Malang

Data yang diperoleh dalam penelitian akan dianalisis menggunakan analisis ragam (uji F) dengan taraf nyata 5\%, dan apabila pada uji $\mathrm{F}$ menunjukkan pengaruh nyata, maka dilanjutkan dengan uji lanjut beda nyata jujur (BNJ) taraf $5 \%$.

\section{Hasil dan Pembahasan}

\section{Respon Pertumbuhan Akibat Penambahan Dosis ZA Tanaman Hiperakumuator Puring dan Lidah Mertua pada Tanah Tercemar Pb}

Hasil penelitian menunjukkan bahwa tidak terdapat pengaruh interaksi nyata pada perubahan tinggi tanaman akibat perlakuan dosis pupuk ZA pada dua macam tanaman Hiperakumulator untuk berbagai umur tanaman disajikan pada Tabel 1. 
Tabel 1. Rata-rata perubahan tinggi tanaman akibat interaksi pemberian beberapa dosis pupuk ZA pada dua macam tanaman hiperakumulator berbagai umur

\begin{tabular}{ccccccc}
\hline \multirow{2}{*}{ Perlakuan } & \multicolumn{7}{c}{ Rata-rata perubahan tinggi $(\mathrm{cm})$ pada berbagai umur hst } \\
\cline { 2 - 7 } & 21 & 28 & 35 & 42 & 49 & 56 \\
\hline $\mathrm{P}_{0} \mathrm{~T}_{1}$ & 0,4 & 1,51 & 2,14 & $-3,43$ & 2,46 & 0,8 \\
$\mathrm{P}_{1} \mathrm{~T}_{1}$ & 0,43 & 1,89 & $-1,82$ & $-0,04$ & 0,68 & 0,08 \\
$\mathrm{P}_{2} \mathrm{~T}_{1}$ & $-0,63$ & 1,01 & $-0,04$ & $-1,57$ & 0,7 & $-0,18$ \\
$\mathrm{P}_{0} \mathrm{~T}_{2}$ & $-1,36$ & 0,26 & $-2,13$ & $-0,31$ & 0,55 & 0,19 \\
$\mathrm{P}_{1} \mathrm{~T}_{2}$ & $-0,41$ & $-1,88$ & $-1,35$ & $-0,3$ & 0,95 & $-0,14$ \\
$\mathrm{P}_{2} \mathrm{~T}_{2}$ & 0,18 & 0,01 & 2,26 & $-2,88$ & 0,1 & 0,05 \\
\hline BNJ5\% & $\mathrm{TN}$ & $\mathrm{TN}$ & $\mathrm{TN}$ & $\mathrm{TN}$ & $\mathrm{TN}$ & $\mathrm{TN}$
\end{tabular}

Keterangan: - Angka yang diikuti dengan huruf yang sama menunjukkan tidak berbeda nyata pada uji BNJ $5 \%$,

- Tanda $(-)=$ terjadi penurunan tinggi tanaman. TN : Tidak Nyata,

- hst : Hari Setelah Tanaman

Tabel 2. Rata-rata perubahann jumlah daun tanaman akibat interaksi pemberian beberapa dosis pupuk ZA pada dua macam tanaman hiperakumulator berbagai umur

\begin{tabular}{ccccccc}
\hline \multirow{2}{*}{ Perlakuan } & \multicolumn{5}{c}{ Rata-rata perubahan jumlah daun (helai) pada berbagai umur hst } \\
\cline { 2 - 7 } & 21 & 28 & 35 & 42 & 49 & 56 \\
\hline $\mathrm{P}_{0} \mathrm{~T}_{1}$ & 0,00 & 0,00 & 0,89 & 1,00 & 1,78 & $-0,67$ \\
$\mathrm{P}_{1} \mathrm{~T}_{1}$ & $-0,11$ & 0,11 & 1,89 & 0,44 & 2,22 & $-0,11$ \\
$\mathrm{P}_{2} \mathrm{~T}_{1}$ & 0,56 & $-0,22$ & 1,11 & 0,89 & 0,67 & 0,11 \\
$\mathrm{P}_{0} \mathrm{~T}_{2}$ & 0,00 & 0,00 & 0,00 & 0,00 & 0,00 & 0,00 \\
$\mathrm{P}_{1} \mathrm{~T}_{2}$ & 0,00 & 0,00 & 0,00 & 0,00 & 0,00 & 0,00 \\
$\mathrm{P}_{2} \mathrm{~T}_{2}$ & 0,00 & 0,00 & 0,00 & 0,00 & 0,00 & 0,00 \\
\hline BNJ5\% & $\mathrm{TN}$ & $\mathrm{TN}$ & $\mathrm{TN}$ & $\mathrm{TN}$ & $\mathrm{TN}$ & $\mathrm{TN}$ \\
\hline
\end{tabular}

Keterangan: - Angka yang diikuti dengan huruf yang sama menunjukkan tidak berbeda nyata pada uji BNJ $5 \%$,

- Tanda (-) = terjadi penurunan tinggi daun. TN : Tidak Nyata,

- hst : Hari Setelah Tanaman

Berdasarkan hasil penelitian diketahui bahwa penambahan beberapa dosis pupuk ZA dan macam tanaman hias yang dicoba menunjukkan respon pertumbuhan yang berbeda-beda. Pengamatan perubahan tinggi tanaman tidak menunjukkan pengaruh yang nyata $(p<0.05)$ (Tabel 1$)$, pengamatan perubahan jumlah daun selama pengamatan tidak menunjukkan pengaruh yang nyata (Tabel 2).

Rosyidah et al., (2014) menjelaskan bahwa cekaman logam $\mathrm{Pb}$ menyebabkan terganggunya pembesaran dan pembelahan sel, transfer energi, fotosintesis, metabolisme lainnya sehingga tidak terjadi pengaruh yang nyata pada dua variabel 
yang diamati. Pada variabel luas daun (Tabel 2) tidak terjadi interaksi antara macam tanaman hias dan berbagai dosis ZA. Menurut Wati et al., (2019) kelebihan pupuk ZA diikarenakan kandungan unsur $S$ (sulfur). Tanaman membutuhkan Sulfur untuk pembentukan hijau daun, meningkatkan kandungan protein dan jumlah anakan. Paparan $\mathrm{Pb}$ akan menghasilkan daun yang mengalami klorosis (daun pucat) dan nekrosis (mengering). Paparan logam berat menyebabkan menurunnya konsentrasi pigmen daun secara tidak langsung sebagai akibat menurunnya laju transport Fe ke daun, yang berakibat pada terganggunya sintesis pigmen.

\section{Konsentrasi Pb di Tajuk, Akar, dan Tanah Tanaman Puring dan Lidah Mertua}

Hasil penelitian menunjukkan bahwa terdapat pengaruh interaksi nyata antara perlakuan akibat penambahan beberapa dosis ZA tanaman hiperakumuator puring dan lidah mertua terhadap konsentrasi logam $\mathrm{Pb}$ di tanah, akar, dan tajuk. Rata-rata konsentrasi $\mathrm{Pb}$ di tanah, akar, dan tajuk disajikan pada Tabel 3.

Tabel 3. Analisis konsentrasi $\mathrm{Pb}$ di tajuk, akar, dan tanah akibat penambahan beberapa dosis ZA tanaman hiperakumuator puring dan lidah mertua konsentrasi logam $\mathrm{Pb}$

\begin{tabular}{cccc}
\hline \multirow{2}{*}{ Perlakuan } & \multicolumn{3}{c}{ Konsentrasi Pb $(\mathrm{ppm})$} \\
\cline { 2 - 4 } & $\mathrm{Pb}$ Tajuk & $\mathrm{Pb}$ Akar & $\mathrm{Pb}$ Tanah \\
\hline P0T1 & $0,24 \mathrm{ab}$ & $0,35 \mathrm{ab}$ & $0,54 \mathrm{c}$ \\
P1T1 & $0,31 \mathrm{c}$ & $0,44 \mathrm{c}$ & $0,51 \mathrm{~b}$ \\
P2T1 & $0,30 \mathrm{c}$ & $0,32 \mathrm{a}$ & $0,48 \mathrm{a}$ \\
P0T2 & $0,22 \mathrm{a}$ & $0,33 \mathrm{ab}$ & $0,54 \mathrm{c}$ \\
P1T2 & $0,29 \mathrm{bc}$ & $0,37 \mathrm{~b}$ & $0,53 \mathrm{c}$ \\
P2T2 & $0,22 \mathrm{a}$ & $0,34 \mathrm{ab}$ & $0,53 \mathrm{c}$ \\
\hline BNJ5\% & 0,03 & 0,04 & 0,02 \\
\hline
\end{tabular}

Keterangan: - Angka yang diikuti dengan huruf yang sama menunjukkan tidak berbeda nyata pada uji BNJ $5 \%$,

Berdasarkan hasil analisis ragam beberapa dosis pupuk ZA dan macam tanaman hiperakumuator yang dicoba menunjukkan pengaruh yang nyata $(p>0.05)$ terhadap konsentrasi $\mathrm{Pb}$ di tajuk, akar dan tanah (Tabel 3). Rata-rata konsentrasi Pb tertinggi di tajuk pada perlakuan P1T1 (dosis pupuk ZA 100kg N/ha dengan tanaman puring) dan tidak berbeda nyata dengan P2T1 (dosis pupuk ZA 200kg N/ha dengan tanaman lidah mertua) dan P1T2 (dosis pupuk ZA 100kg N/ha). Rata-rata konsentrasi Pb di akar tertinggi pada perlakuan P1T1 (dosis pupuk ZA 100kg N/ha). Rata-rata konsentrasi Pb tertinggi di tanah pada perlakuan P0T1 (dosis pupuk ZA 0kg N/ha) tidak berbeda nyata dengan perlakuan P0T2 (dosis pupuk ZA 0kg N/ha dengan tanaman lidah mertua), P1T2 (dosis pupuk ZA $100 \mathrm{~kg} \mathrm{~N} /$ ha dengan tanaman lidah mertua), dan P2T2 (dosis pupuk ZA $200 \mathrm{~kg} \mathrm{~N} /$ ha dengan tanaman lidah mertua) (Tabel 3). 
Rata-rata konsentrasi Pb di tajuk dan akar tertinggi pada perlakuan P1T1 (dosis pupuk ZA $100 \mathrm{~kg} \mathrm{~N} / \mathrm{ha}$ dan tanaman puring) 0,31 ppm dan 0,44 ppm diduga karena serapan $\mathrm{Pb}$ dari akar di translokasikan ke tajuk sebagai akibat transpirasi. Menurut Gupta dan Sinha (2008), bahwa vakuola atau dinding sel yang berada pada akar dapat mensekuestrasi logam hal ini dapat membantu agar logam tidak bergerak ke tajuk tanaman. Pernyataan yang sama juga diungkapkan oleh Yoon et al., (2006) yang menyatakan terkadang akar juga mempunyai sistem penghentian transpor logam menuju daun terutama logam non esensial, sehingga ada penumpukkan logam di akar. Logam $\mathrm{Pb}$ sebagai salah satu logam non esensial bagi tanaman memiliki kecenderungan ditumpuk oleh akar, dari pada ditransfer ke bagian tajuk.

\section{Translocation Factor (TF) Tanaman Puring dan Lidah Mertua}

Hasil penelitian menunjukkan adanya pengaruh interaksi nyata antara perlakuan akibat penambahan beberapa dosis ZA tanaman hiperakumuator puring dan lidah mertua TF. TF disajikan pada Tabel 4.

Tabel 4. Rata-rata TF tanaman akibat pemberian beberapa dosis pupuk ZA pada dua macam tanaman Hiperakumulator Umur 56 hst.

perlakuan

\begin{tabular}{cc}
\hline P0T1 & $0,69 \mathrm{ab}$ \\
P1T1 & $0,70 \mathrm{ab}$ \\
P2T1 & $0,95 \mathrm{c}$ \\
P0T2 & $0,67 \mathrm{a}$ \\
P1T2 & $0,78 \mathrm{~b}$ \\
P2T2 & $0,64 \mathrm{a}$ \\
\hline BNJ5\% & 0,11
\end{tabular}

Keterangan: - Angka yang diikuti dengan huruf yang sama menunjukkan tidak berbeda nyata pada uji BNJ 5\%

Translocation Factor (TF) logam berat adalah nilai yang menunjukkan kemampuan logam berat untuk ditransfer dari akar ke tajuk (Sugiyanto, 2016). Berdasarkan hasil analisa ragam perhitungan TF menunjukkan adanya pengaruh interaksi yang nyata ( $p>0.05)$ antara macam tanaman hias dan berbagai dosis pupuk $\mathrm{ZA}$. Hasil perhitungan logam berat $\mathrm{Pb}$ berkisar antara 0,64 sampai 0,95 yang artinya niai $T F<1$ (Tabel 20). Nilai TF tertinggi terdapat pada tanaman puring yaitu perlakuan P2T1 (dosis pupuk ZA 200kg N/ha dengan tanaman puring) sebesar 0,95 ppm dan pada tanaman Lidah mertua yaitu perlakuan P1T2 (dosis pupuk ZA $100 \mathrm{~kg} \mathrm{~N} / \mathrm{ha}$ dengan tanaman Lidah mertua) sebesar 0,78 ppm. Yang artinya bahwa P2T1 dan 
P1T2 lebih baik dalam mentranslokasikan pb dari akar ke taju tanaman. Lorestani et al., 2011; Yoon et al., 2006 menjelaskan bahwa apabila nilai TF $<1$ maka tanaman dikategorikan pada strategi fitoremediasi fitostabilisasi.

Ma et al., (2001), salah satu cara mengurangi kontaminasi logam berat yang hemat tenaga dan biaya adalah melalui fitoremediasi. Salah satu aplikasi dari fitoremediasi yaitu fitostabilisasi. Pengertian dari fitostabilsasi yaitu salah satu strategi untuk mengurangi kandungan polutan seperti logam di tanah. Dalam fitostabilisasi, konsentrasi logam yang ada pada tajuk lebih rendah dibandingkan yang berada di akar. Pada tanaman puring dan lidah mertua yang dihitung berdasarkan konsentrasi logam dalam tajuk dan akar tanaman menunjukkan bahwa tanaman ini toleran logam berat atau dapat menjadi strategi untuk fitostabilisasi.

Hasil uji BNJ 5\% menunjukkan bahwa serapan $\mathrm{Pb}$ di akar dan tajuk menunjukkan berbeda nyata. Gambar dibawah ini munjukkan hubungan dosis pupuk ZA dengan serapan $\mathrm{Pb}$ di akar. Gambar dibawah ini meunjukkan hubungan dosis pupuk ZA dengan serapan $\mathrm{Pb}$ di akar dan tajuk. Berdasarkan Gambar 1 hubungan antara dosis pupuk ZA pada serapan $\mathrm{Pb}$ di akar ada kecenderungan mengikuti pola kuadratik yang artinya semakin tinggi dosis pupuk ZA hingga tingkat tertentu kadar serapan $\mathrm{Pb}$ di akar semakin tinggi, melampai titik tersebut kadar serapan $\mathrm{Pb}$ di akar menurun. Berdasarkan regresi pada tanaman puring $T 1=-0,00001 \times 2+0,0019 x+0,3485$ dengan nilai determinasi (tingkat pengaruh dosis ZA terhadap kadar serapan $\mathrm{Pb}$ di akar tanaman puring) sebesar 0,94\% diperoleh dosis optimum pupuk ZA 95kg N ha-1 dengan kadar serapan $\mathrm{Pb}$ 0,43875 ppm. Dan berdasarkan persamaan regresi pada tanaman lidah mertua $\mathrm{T} 2=-0,000003 \times 2+0,0007 \mathrm{x}+0,333$ dengan nilai determinasi (tingkat pengaruh dosis ZA terhadap kadar serapan $\mathrm{Pb}$ di akar tanaman Lidah mertua) sebesar $0,82 \%$ diperoleh dosis optimum pupuk ZA $116,7 \mathrm{~kg} \mathrm{~N}^{\mathrm{N}} \mathrm{ha}^{-1}$ dengan kadar serapan $\mathrm{Pb} 0,37383 \mathrm{ppm}$. 


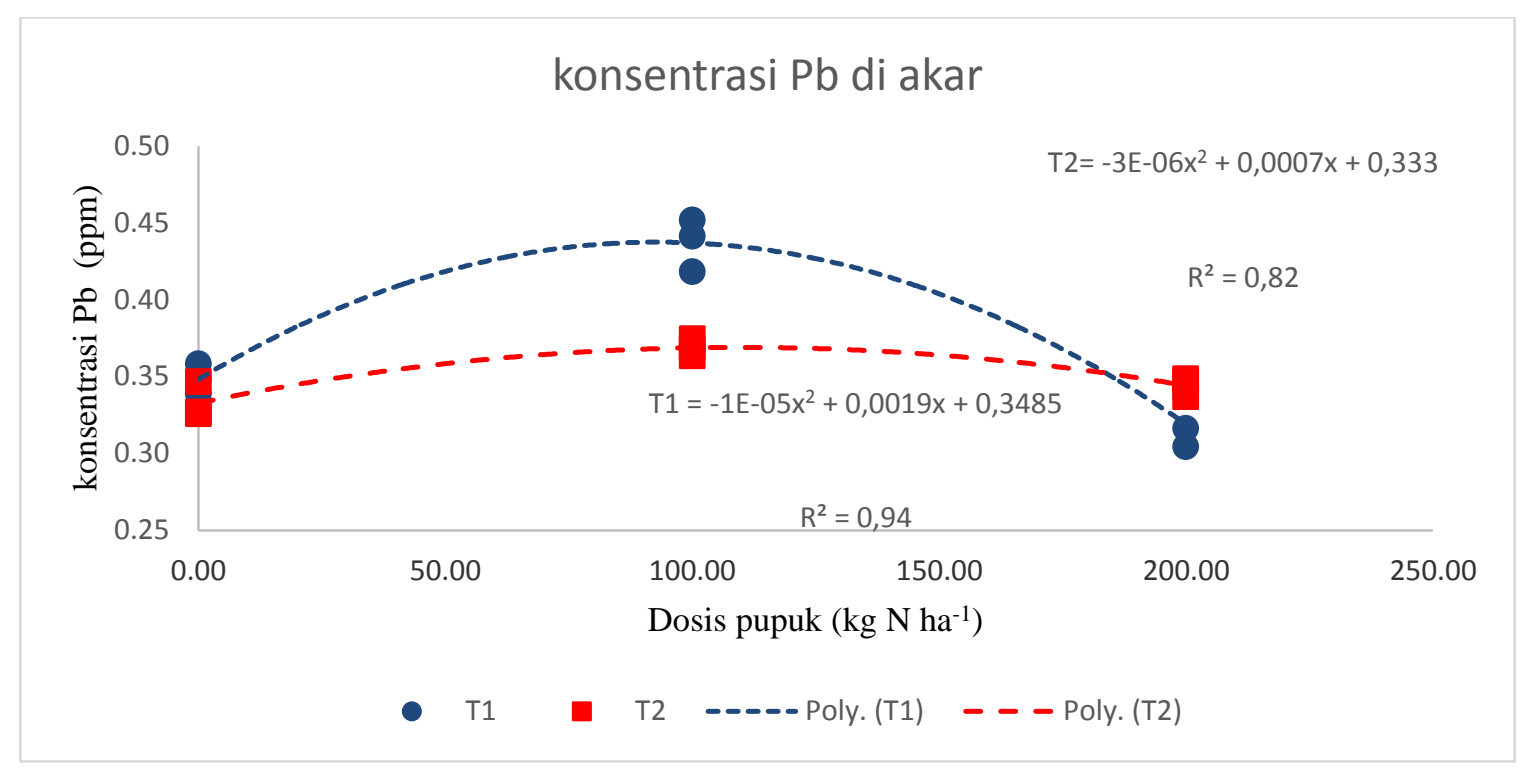

Gambar 1. Grafik hubungan dosis pupuk ZA dengan serapan Pb pada akar ( $\mathrm{T} 1=$ Puring, T2= Lidah mertua)

\section{Kesimpulan dan Saran}

Puring (Codiaeum variegatum L.) dan tanaman lidah mertua (Sansevieria trifasciata L.) sebagai tanaman indikator dalam penelitian ini menunjukkan efek pertumbuhan yang berbeda-beda. Interaksi perlakuan macam tanaman hias dan beberapa dosis pupuk ZA tanaman puring dan tanaman Lidah mertua pada beberapa umur tidak memberikan pengaruh nyata terhadap pertambahan tinggi tanaman, pertambahan jumlah daun, dan pertambahan luas daun. Kandungan $\mathrm{Pb}$ di tajuk dan akar tertinggi pada perlakuan P1T1 (dosis pupuk ZA $100 \mathrm{~kg} \mathrm{~N} /$ ha dan tanaman puring) 0,31 ppm dan 0,44 ppm diduga karena serapan $\mathrm{Pb}$ dari akar di translokasikan ke tajuk Macam tanaman hias dan pemberian beberapa dosis pupuk ZA pada tanaman puring dan tanaman lidah mertua yang telah dicoba menunjukkan bahwa dosis optimum pupuk ZA pada tanaman puring $95 \mathrm{~kg} \mathrm{~N} /$ ha dengan kadar serapan $\mathrm{Pb}$ 0,43875 ppm dan tanaman lidah mertua $116,7 \mathrm{~kg} \mathrm{~N} / \mathrm{ha}$ dengan kadar serapan $\mathrm{Pb}$ 0,37383 ppm. Berdasarkan hasil penelitian disarankan tanah yang tercemar $\mathrm{Pb}$ dapat dilakukan remediasi dengan menggunakan tanaman puring dosis pupuk ZA $95 \mathrm{~kg} \mathrm{~N} / \mathrm{ha}$ dan lidah mertua dosis pupuk ZA 116, $7 \mathrm{~kg} \mathrm{~N} / \mathrm{ha}$.

\section{Daftar Pustaka}

Gupta, Y., M. M. Sinha. 2008. Phonon properties of iron-based superconductors. Aip Conference Proceeding. 1953(1): 110028.

Gurnita, N. Sondari, dan R. Budiasih. 2017. Pengaruh pengindus Ammonium Sulfat terhadap pertumbuhan dan kandungan logam berat Timbal $(\mathrm{Pb})$ pada rumput akar 
wangi (Vetiveria zizanoides L.) yang ditanam pada Tailing Tambang Emas. Biosfer, Jurnal Biologi dan Pendidikan Biologi 2 (1): 26-35

Kurniawati, L., H. S. Syamsidar, K. Ramadani. 2016. Fitoremediasi logam cadmium (Cd) dari asap rokok menggunakan tanaman puring (Codiaeum variegatum). AlKimia, 4: 1.

Mangkoedihardjo, S. 2005. Remediation technologies selection for oil-polluted marine ecosystem. Jurusan Teknik Lingkungan, Fakultas Teknik Sipil dan Perencanaan, Institut Teknologi Sepuluh Nopember. Surabaya

Mukhlis, Sarifuddin, dan Hanum. 2011. Kimia Tanah. Medan: USU Press. Hal: 193194.

Rosidah, S, U. Yustinus, K. Krispinus, 2014. Uji toleransi tanaman Tembakau (Nicotiana Tabacum L.) Terhadap cekaman kadmium (Cd), timbal (Pb), dan tembaga (Cu) pada kultur cair. Jurnal MIPA. 37(1): 7-15.

Wati, D. R., A. Sholihah, dan A. Rosyidah. 2019. Respon tanaman hias puring (Codiaeum variegatum L.) dan lidah mertua (Sansevieria trifasciata L.) akibat penambahan macam pupuk nitrogen pada tanah tercemar logam berat timbal (Pb). AGRONISMA. 7(1): 84-90.

Yoon, J., C. Xinde, Z. Qizing and L.Q. Ma. 2006. Accumulation of $\mathrm{Pb}, \mathrm{Cu}$, and $\mathrm{Zn}$ in native plants growing on a contaminated florida site. Science of the Total Environment, 358 (1): 456-464.

Yusuf, M, Z. Achmad, A. Ardy. 2014. Fitoremediasi tanah tercemar logam berat $\mathrm{Pb}$ dan Cd dengan menggunakan tanaman lidah mertua (Sansevieria trifasciata). (Skripsi). Universitas Hasanuddin. 